\title{
“Talking About Sexual Orientation, Teaching About HOMOPHOBIA"-NEGOTIATING THE DIVIDE BETWEEN RELIGIOUS BELIEF AND TOLERANCE FOR LGBT RIGHTS IN THE CLASSROOM ${ }^{1}$
}

\author{
TONI LESTER*
}

\section{INTRODUCTION - SEXUALITY POLITICS, RELIGIOUS BELIEF AND THE CLASSROOM}

The question of whether or not people in the LGBT ${ }^{2}$ community should be able to enjoy certain fundamental rights taken for granted by most Americans is a contentious issue. While a large number of people agree that same sex sexuality should no longer be criminalized $^{3}$ and that gay men and lesbians should be allowed to participate in civil unions, ${ }^{4}$ a significant number believe that homosexuality is immoral ${ }^{5}$ and that it should be illegal for gay men and lesbians to marry. ${ }^{6}$ Greater or lesser tolerance for LGBT rights in the U.S., especially gay marriage, is directly tied to age, religious belief and political affiliation. A 2005 nation-wide survey conducted by the Boston Globe found that people thirty-five years old and younger are more pro-gay in their attitudes than plus sixty-five year olds." The same survey revealed that "Republicans, Protestants, regular churchgoers, and Southerners were most likely to oppose gay marriage. It was more likely to be favored by ... Democrats, and people who do not attend worship services or who attend a few times a year."

There are many explanations for why some people are against LGBT rights. For instance, some scholars argue that animus against gay men and lesbians, or homophobia, ${ }^{9}$ stems from repressed feelings of attraction for people of the same

1. My title pays homage to the landmark article by Beverly Daniel Tatum, Talking About Race, Learning About Racism: The Application of Racial Identity Development Theory in the Classroom, 62 HARV. EDUC. REV. 1 (1992).

* J.D. (Georgetown University), Ph.D. (Northeastern University), Professor of Law, Babson College, Board member, Astraea Foundation for Justice, Author: Gender Nonconformity, Race and Sexuality - Charting the Connections (University of Wisconsin Press).

2. I use the acronym, "LGBT," to refer to people in the lesbian, gay, bisexual and transgender community. I use the term "gay," to refer specifically to gay men, and sometimes collectively to gay men and lesbians.

3. Jeni Loftus, America's Liberalization in Attitudes toward Homosexuality, 1973 to 1998, 66 AM. SOC. REV. 762, 778 (2001).

4. Scott S. Greenberger, One Year Later, Nation Divided on Gay Marriage, Split Seen by Region, Age, Globe Poll Finds, BOsTON GLOBE, May 15, 2005, at A1.

5. Loftus, supra note, 3.

6. Greenberger, supra note, 4 .

7. Id.

8. Id.

9. William J. Serdahely and Georgia J. Ziemba, Changing Homophobic Attitudes through College Sexuality Education, 10 J. HomoseXUALITY 109 (1984) (citing M. Freedman, Towards A Gay Psychology, 
sex, feelings that the holder finds repugnant. This in turn can sometimes cause the holder to lash out at gay men and lesbians..$^{10}$ Others contend that homophobia is rooted in sexist attitudes about proper gender roles, with lesbians and gay men being viewed as traitors to nature because of their same sex affiliations. ${ }^{11}$ People who hold the kinds of views just explained, often find support for their ideas in interpretations of the teachings of some of the more conservative strains of the world's major religions.

For example, in 2003, the same year that the Massachusetts Supreme Court's endorsed the legality of same sex marriage, the Vatican announced that "marriage exists solely between a man and woman ... while homosexual acts go against the natural moral law." ${ }^{12}$ The Southern Baptist Convention, America's largest Protestant denomination with 14 million members, ${ }^{13}$ has said that "Homosexuality is not a 'valid alternative lifestyle.' The Bible condemns it as sin." ${ }^{14}$ Furthermore, the African Methodist Episcopal Church, one of the oldest African American Christian denominations, has announced that it considers same sex marriage and the ordination of gay clergy contrary to church doctrine. ${ }^{15}$

This is not to say that all religious denominations are against LGBT rights. The Unitarian Universalist Association endorses the ordination of openly lesbian, gay and bisexual ministers, ${ }^{16}$ as does the United Church of Christ. ${ }^{17}$ In an official pronouncement, the latter stated: "We recognize the presence of ignorance, fear and hatred in the church and in our culture, and covenant to not discriminate on the basis of sexual orientation ..., and we seek to include and

ThE Gay ACADEMIC (ETC Publications: Palm Springs, CA, 1978) (explaining that the term "homophobia" refers to the "emotional feelings of anxiety, ... aversion, anger, discomfort, and fear that heterosexuals may experience in dealing with .. . [gay men and lesbians].").

10. Leonard L. Glass, Man's Man/Ladies' Man: Motifs of Hypermasculinity, 47 PsYCHIATRY 260, 263 (1984).

11. Toni Lester, Protecting the Gender Nonconformist from the Gender Police - Why The Harassment of Gays Is A Form of Sex Discrimination in Light of the Supreme Court's Decision in Oncale v. Sundowner, 29 N.M. L. REV. 89-118 (1999).

12. Vatican fights gay marriages, CNN, July 31, 2003, available at http://www.cnn.com/2003/ WORLD/europe/07/31/vatican.gay.marriage (last viewd Aug. 5, 2003).

13. "[The $\mathrm{SBC}] \ldots$ is the second largest grouping of Christians in the United States, after the Roman Catholic Church." "Southern Baptist Convention," available at http://en.wikipedia.org /wiki/Southern_Baptist_Convention (last viewed April 7, 2008).

14. Position Statements on Sexuality, OfFICIAL WEBSITE OF THE SOUTHERn BAPTIST CONVENTION, available at http://www.sbc.net/aboutus/pssexuality.asp (last viewed Mar. 5, 2008).

15. Stances of Faiths on GLBT Issues: African Methodist Episcopal Church, HUMAN RIGHTS CAMPAIGN, available at http://www.hrc.org/issues/4957.htm (last visited Mar. 5, 2008).

16. History of Unitarian Universalist Involvement in and Support of Bisexual, Gay, Lesbian and Transgender Issues, available at http://www.uua.org/members/justicediversity/bisexualgay/ 20962.shtml (last viewed April 7, 2008.

17. United Church of Christ, Resolution on Affirming Gay, Lesbian and Bisexual Persons and their Ministries, June 27-July 2, 1991, available at http://www.ucc.org/assets/pdfs/1991-RESOLUTIONON-AFFIRMING-GAY-LESBIAN-BISEXUAL-PERSONS-AND-THEIR-MINISTRIES.pdf. 
support those who, because of this fear and prejudice, find themselves in exile from a spiritual community." ${ }^{18}$

It should not be forgotten that America, a majority Christian country, is a land of multiple religions. The following is only an imperfect sampling of the official views on homosexuality held by several non-christian religious groups with sizeable followings in the United States. Reform Judaism, the biggest Jewish denomination in the United States with 1.7 million members, welcomes openly gay rabbis and members and endorses same sex commitment ceremonies. ${ }^{19}$ However, such ceremonies are not considered the same as heterosexual marriage ceremonies. ${ }^{20}$ On the other hand, the Conservative Judaism movement, which has 1.4 million members in the United States, officially prohibits same sex weddings and openly lesbian or gay rabbis. ${ }^{21}$

Among the 6 million Muslims who reside in the United States ${ }^{22}$, the pro U.S. Muslim advocacy organization, Al-Fatiha, says: "There is a general consensus amongst the scholars of Islam (both past and present) that homosexuality is a deviation of man's true heterosexual nature. ${ }^{23}$ Nevertheless, the British based Muslim pro-LGBT organization, Safra, says that it is "important to remember that there is no one definitive opinion on issues relating to sexuality, gender and Islam. In fact, there are a number of scholarly opinions and even shari'ah, i.e., rules and laws derived from the Koran and the teachings of the Prophet Mohammad, is made up of a number of diverse opinions." ${ }^{24}$

Finally, there are 1.5 million Hindus in the United States. ${ }^{25}$ According to author Ruth Vanita, author of Same Sex Love in India: Readings from Literature and History, Hindu law regards same sex sexuality as impure. However, it does not exact the same penalties for engaging in it as it does for those who commit adultery or rape. ${ }^{26}$ Today, while there are many LGBT Hindu organizations in the U.S. and some Hindus who have expressed an openness to the possibility of LGBT rights, most Hindu religious communities have failed to directly address the issue of LGBT rights or relationships within their midsts. ${ }^{27}$

It is into this fray of political and religious contentiousness that $I$, a longtime civil and LGBT rights advocate and scholar with over nineteen years of

18. Stances on Faith of GLBT Issues: United Church of Christ," Human Rights Campaign, available at http:/ /www.hrc.org/issues/religion/5055.htm (last viewed on April 7, 2008).

19. Stances on Faith of GLBT Issues: Judaism, Human Rights Campaign, available at http:/ / www.hrc.org/issues/religion/5013.htm (last viewed on April 7, 2008).

20. Id.

21. Id.

22. Stances on Faith of GLBT Issues: Islam, Human Rights Campaign, available at http://www .hrc.org/issues/religion/5007.htm (last viewed on April 7, 2008).

23. Id.

24. Sexuality, Gender \& Islam, SAFRA PROJECT, available at http://www.safraproject.org/sgiintro.htm (last viewed Mar. 5, 2008).

25. Ruth Vanita, "Stances on Faith of GLBT Issues: Hinduism," Human Rights Campaign, available at

http:/ /www.hrc.org/issues/religion/4997.htm (last viewed on April 7, 2008).

26. Id.

27. Id. 
teaching experience, have entered in order to teach an advanced elective I developed, called "Intolerance, Culture and the Law." The course, which has been taught to 119 students over a nine year period, explores how the law reflects, challenges and shapes attitudes people hold about differences relating to religion, race, gender and sexuality by looking at relevant theory and the connections between cultural and historical developments and legal thought. My main objective in the course is to help students become well-versed in the literature of identity politics and to develop greater open-mindedness and tolerance for people who embody non-majority culture differences.

The intolerance course is divided into four sections - religion, race, gender and LGBT issues. This article will reflect on my experience teaching the segment on LGBT issues. The course has become one of the most popular of its kind, and I want to examine why this is the case. It is my hope that the insights garnered here will be of use to other people teaching about this most important and timely topic. Until recently, the teaching materials I assign have focused almost exclusively on lesbian and gay rights, as opposed to the rights of bisexuals and transgendered people. My discussion will therefore predominantly cover pedagogical issues relating to those topics. A significant amount of my discussion will stem from the results of a questionnaire I give to students at the end of each semester, which asks them a series of open-ended questions about the effectiveness of certain pedagogical techniques I use to achieve course objectives. The student quotes mentioned throughout this article all come from answers to this questionnaire.

It should come as no surprise that all of the societal perspectives discussed above are represented in my classes. College can be home to students from a variety of differing backgrounds, lifestyles, religious traditions and political persuasions. Some students haven't given much thought to the topic of LGBT rights. Others are either adamantly against LGBT rights or passionately for them. One thing all of my students have in common, however (based on what I have observed during my many years of teaching), is that they are not used to talking to each other without becoming dismissive of opposing perspectives about any politically controversial issue, much less LGBT rights. In these times of entrenched political ideologies, where politicians tend to demean people who hold views that differ from their own, it is critical that young adults be given the space to engage in a constructive dialogue across social and cultural differences.

Such dialogue is not without its challenges, however, as a recent study by Emory University psychologist and neuroscientist, Dr. Drew Weten, demonstrates. $^{28}$ Dr. Weten and his colleagues used MRI scanners to see what happens in the brains of politically partisan people when they are offered information that contradicts their views. ${ }^{29}$ Weten found that, while people normally use the rational "cold reasoning" part of their brain to translate most contradictory information, they use regions of the brain associated with irrational emotion to compute politically charged, contradictory information. ${ }^{30}$

28. A Shocker: Partisan Thought Is Unconscious, New York Times, Jan. 24, 2006, at F1 (Science).

29. Id.

30. Id. 
As Weten says, a person can counter these biases, but they have to "engage in ruthless self-reflection, to say, 'All right, I know what I want to believe, but I have to be honest.' " 31 I encourage my students to engage in the same kind of ruthless self-reflection.

An engagement of this type over a sustained, semester-long period does not come without its challenges. Discussing how white college students react to learning about racism, Beverly Tatum explains: "the introduction of . . . issues of oppression often generate powerful emotional responses in students that range from guilt and shame to anger and despair. If not addressed, these emotional responses can result in student resistance to oppression-related content . . . ."132

Heterosexual students of all races exhibit similar levels of resistance to materials that challenge their received negative wisdoms about the LGBT community. That resistance can include engaging in confrontational debates with the professor and other classmates, refusing to talk in class altogether, skipping class or failing to complete assignments on time. Over and over again, however, I have seen students move from a place of resistance to one in which they become, as one of my former students describing her/his own transformation put it: "more empathetic to practices, customs, or traits that fall outside what... [they are] used to." Such transformation is possible when students are encouraged to voice their feelings in a setting that challenges them to unpack their prejudices in a safe, yet intellectually rigorous manner.

Part One will describe my teaching philosophy and the course's design. Part Two will describe the questionnaire's design and methodology. Part Three will analyze the questionnaire's results, and Part Four will consist of my conclusions.

\section{PART ONE: TEACHING PHILOSOPHY, COURSE \\ READINGS AND PEDAGOGICAL TECHNIQUES TEACHING PHILOSOPHY}

My chief teaching objective is to give students a strong foundation in the principles of law, culture and society so that they will become good thinkers and, hopefully, good citizens. Students can attain these characteristics if they acquire the requisite critical thinking skills, and learn how to communicate their views in a way that encourages others to think insightfully. I strive to cultivate all of these qualities in students through the use of various pedagogical techniques and assignments.

My stance as a teacher is very different from the stance I take in the world at large, where I am a strong and vocal advocate for LGBT rights. In the classroom, I play the role of facilitator and mediator, assisting and supporting students in their discovery of the embedded meaning in readings and assignments, and in their cultivation of communication skills that enables them to talk openly and effectively about these meanings to each other and to me. I also try to establish trust between myself and the class by telling them that all viewpoints are welcome, and that no student will be penalized for having a

31. Id.

32. Tatum, supra note 1 , at $1-2$. 
viewpoint that differs from my own or any other student. Every assignments and exam I give has a component that asks students to voice their personal views and react to the materials. Since my grading focuses exclusively on substantive coverage of the topics researched, the application of logic, written grammar and syntax, and inventiveness of thought, students quickly see that they can indeed express themselves freely without negatively impacting their grade. As a result, many start to take a similar nonjudgmental approach with each other. This, of course, has the potential to manifest itself in their interactions with others outside the classroom. Student responses on the questionnaire generally support that these techniques work.

As one student writing on his/her questionnaire in response to a question I posed about the effectiveness of my teaching approach observed: "Your style of teaching is different than other teachers ... because you let us talk, and argue, and you guide the conversation but you don't say what you feel [explicitly]. And this is good because we tend to side with and accept as true information and opinions provided by an older authority - like a teacher." And another said:

I think your thoughts and words come from your well-rounded, non discriminatory, negotiation of your experiences and relationships with people. Your teachings are like "law abiding" legislative based discovery of experience and identity ... hands free teaching method that doesn't tell students what to think, but allows for a reactionary display of all kinds of information you provide and then a more thorough learning experience for those who listen to other students with an open, but analytical mind.

While I try my best to model all of the above qualities, this does not mean I shirk my responsibility to, as bell hooks suggests, "teach to transgress." ${ }^{\prime 3}$ In fact, students would be hard pressed not to notice that many, although not all, of the readings I assign are written by critical race, feminist and queer scholars who challenge traditional notions of gender, race and sexuality. While the LGBT students and non-LGBT students who support LGBT rights usually express gratitude for the inclusion of these materials, other students not falling into these two categories sometimes chafe at the same prospect, a few even protesting that the course has a not-so-hidden liberal agenda. But as bell hooks has said, "no education is politically neutral ... a white male professor in an English department who teaches only work by 'great white men' is making a political decision .... ." What is most important, then, is to encourage students to react to whatever makes them uncomfortable in a well-informed and reasoned manner, regardless of where they fall on the political spectrum.

\section{A. Course Readings}

Over the years, I have assigned a wide variety of readings relating to LGBT topics that cover historical and legal works, and sources from contemporary culture, such as films and literature. For instance, students sometimes read John

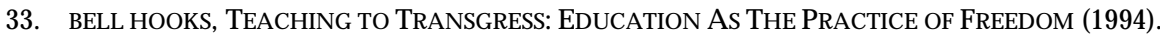

34. Id. at 37 . 
D'Emilio's "Capitalism and Gay Identity" ${ }^{35}$ or excerpts from the anthology, "Hidden from History: Reclaiming the Gay and Lesbian Past" ${ }^{36}$ to learn about theories on the origins of modern gay identity. With respect to the tensions that exist between certain religious denominations and the LGBT community and general issues relating to religious intolerance, I assign chapters from John Boswell's "Christian Tolerance of Homosexuality" ${ }^{137}$ and excerpts from Chris Bull and John Gallagher's "Perfect Enemies - The Religious Right, the Gay Movement and the Politics of the 1990s." ${ }^{38}$

We also watch the documentary, The Longest Hatred ${ }^{39}$, which is about the relationship between early Christianity and anti-Semitism. I show the documentary, not to target Christianity per se, but to demonstrate how groupthink and the stigmatization of others manifest itself in systems of societal power, as was the case with the Church during the time of its inception. Books such as Eric Brandt's "Dangerous Liasons: Blacks, Gays, and the Struggle for Equality $^{\prime \prime 40}$ are included to expose students to some of the debates taking place within the LGBT community about the marginalization of ethnic and racial minorities within its ranks, and Judith Butler's "Gender Trouble" ${ }^{\prime 11}$ to expose students to early queer theory scholarship.

Legal texts include Bowers v. Hardwick, ${ }^{42}$ the Supreme Court decision upholding laws criminalizing gay sex, and Lawrence v. Texas, ${ }^{43}$ the 2003 Supreme Court decision overturning Bowers. I also assign Goodridge v. Dep't of Public $\mathrm{Health}^{44}$, the Massachusetts state Supreme Court decision declaring gay marriage legal in the state of Massachusetts. Films include such documentaries as the Celluloid Closet, ${ }^{45}$ on the treatment of gay men and lesbians in popular film, and Both of My Moms' Names Are Judy, ${ }^{46}$ a documentary about the children of lesbian and gay men.

\section{B. Pedagogical Techniques: Class Participation and Writing Assignments}

The course is conducted in a seminar format that combines lectures and class discussion. Guest speakers are invited from time to time. Two handouts

35. John D'Emilio, Capitalism and Gay Identity, in THE LESBIAN AND GAY STUDIES READER 467-76 (Henry Abelove, et al. eds., 1993).

36. HidDEN FROM History: RECLAIMING THE GAY AND LESBIAN PAST (George Chauncey, Jr. et al. eds., 1990).

37. D'Emilio, supra note, 35.

38. Chris Bull \& John Gallagher, Perfect Enemies - The Religious Right, the Gay MOVEMENT AND THE POLITICS OF THE 1990s (1996).

39. THE LONGEST HATRED (WGBH Boston 1993).

40. Eric Brandt, DANGEROUS LIASONS: BLACKS, GAYS, AND THE STRUGGLE FOR EQUALITY (1999).

41. JUdith ButLER, GENDER TROUBLE: FEMINISM AND THE SUBVERSION OF IDENTITY (1990).

42. 478 U.S. 186 (1986).

43. 539 U.S. 558 (2003).

44. 798 N.E.2d 941 (Mass. 2003).

45. The Celluloid Closet (TriStar Pictures 1995).

46. Both OF My Moms' NAmes ARE Judy: CHILDREN OF LESBIANS AND GAYs SPEAK OUt (The Lesbian and Gay Parents Association 1995). 
are given at the start of the term that set clear criteria about how students are expected to participate in class.

\section{Class Participation}

Much has been written about how the "the politics of domination" ${ }^{47}$ are replicated in the college classroom when one or only a few voices (typically men vs. women, whites vs. people of color or heterosexuals vs. LGBT people) take center stage. Explaining how this dynamic occurs in a racially diverse classroom setting, bell hooks says: "Often, if there is one lone person of color in the classroom, she or he is objectified by others and forced to assume the role of 'native informant'." ${ }^{\prime 8}$ LGBT students risk similar forms of silencing, on the one hand, and objectification, on the other. Furthermore, young adults influenced by homophobic messages found in popular music and culture, as well as in their families and communities of origin, sometimes unwittingly (and sometimes, unfortunately, wittingly) use language in the classroom that many students find derogatory and insulting. Talking about the painful effect that this kind of speech can have on LGBT people and other minorities, Charles Lawrence has said: "Fear, rage, shock, and flight all interfere with any reasoned response. Words like 'nigger,' 'kike,' and 'faggot' produce physical symptoms that temporarily disable the victim, and the perpetrators often use these words with the intention of producing this effect. Many victims do not find words of response until well after the assault . . . [has occurred]. ${ }^{\prime 49}$

A tone must therefore be set early on that shows students that, while the free expression of ideas is highly encouraged, certain fundamental standards of respect need to be adopted so that everyone has full access to the learning environment. I set this tone by asking students to sign on to a set of ground rules. The ground rules ask students to try not to make generalized or stereotyped statements about groups, but instead to focus on their own experiences and feelings. The rules also encourage students to first summarize what they have heard others say before launching into an attack that articulates an opposing viewpoint. Students are asked to bring a heightened sense of awareness and sensitivity to the impulse to use language that has the potential to hurt or harm.

The element of choice is crucial to the effective use of the rules during the term. Students need to feel that they have participated in the development of the rules and that they are not simply being forced to adhere to them. I thus ask students to read the rules aloud to one another during the first day of class, and to suggest additional items to add to the list. I tell them they can demonstrate their concurrence with the rules by returning to the next session, since the course is an elective and students have the option of dropping it without penalty at this point in the term.

47. HOOKS, supra note 33 , at $40-41$.

48. Id. at 43 .

49. Charles Lawrence, If He Hollers Let Him Go: Regulating Racist Speech on Campus, 1990 DUKE L.J. 431, 542-53. 
Students tend to welcome the opportunity to learn how to talk to others outside their comfort zone in the language of conciliation instead of confrontation. Many students tell me that they are relieved to be given an opportunity to frame their feelings in an open and honest way. Of course, one person's version of respect is another person's unfair censoring of free speech. Thus, from time to time, a particular student may adopt a belligerent and offensive tone about LGBT topics, evoking strong negative reactions from others. In such instances, there is a delicate balance that must be negotiated between reminding the student in front of the whole class that certain language is inappropriate or letting the student have his or her say. I usually I find it best to talk to the student outside class about the problem unless I determine that the situation is particularly egregious. The line I draw for myself is fluid and constantly in a state of flux in this regard. Depending on the context and how one feels in the moment in question, that line will be different for each and every individual teacher.

In addition to the above ground rules, the typical class discussion model, in which any student who wants to answer a question the teacher raises or comment on the material can do so on a "first hand up basis," class discussion is organized as follows:

\section{Expert Panels}

In each class a small randomly selected number of students serve as a "panels of experts" on the readings for that day. Experts are always given the first opportunity to answer my questions and to offer comments about the readings before others can make contributions. This approach requires participation of those students who have tended to be quiet in my classes, particularly women, racial minorities and LGBT students. Since students are given advanced notice of when they will be called upon to be experts, the anxiety that cold calling can evoke is substantially reduced. Finally, expert panels encourage students who have not developed good listening skills to become better listeners on the days when they are not assigned to be experts.

\section{Small Groups}

From time to time, I divide students into small discussion groups and ask them to share their reactions to readings or a list of questions. Specific students may be assigned to manage the flow of discussion in these groups and take notes to report to the class on the group discussion. This approach is especially helpful to LGBT students who may not be comfortable sharing with the large group what they might share in the small group. Students in small groups can also avoid having to worry about "performing" for the professor and saying what they think the professor wants to hear. Furthermore, small groups have potential to build cohesion among group members and foster burgeoning friendships across differences. This can help students replace internalized negative group stereotypes with more realistic assessments of individual classmates, regardless of their identity group affiliation. 


\section{Written Assignments}

Writing assignments give students the opportunity to voice their personal feelings about the materials and analyze issues in a balanced, critically-minded manner. Students are sometimes asked to write "on the spot" in-class reaction papers in response to the materials just discussed or read, without having to worry about grammar and syntax. At other times, students are asked to keep a journal over a period of several days that examines their reactions to the topics under review. Students are also assigned more traditional research papers in which, in addition to the traditional summary description and analysis of the issues, I require students to include:

- a section in which the student examines how groups and individuals with differing views on the topic under discussion think about that topic. Thus, if a student writes a paper on gay marriage, that student would also have to explain the Catholic Church's position on gay marriage, as well as an LGBT advocacy group's position on the same subject. This gives students the opportunity to "try on" the other side's point of view in a serious and thoughtful manner, even if they ultimately decide to reject it personally.

- a section in which they share their own personal views on the topic. This section is crucial because it helps establish the trust between myself and the class previously discussed.

\section{Debates}

Like writing assignments, debates allow students to engage in an in-depth examination of LGBT topics. Debates involve small, randomly assigned groups of students who are assigned to research a topic and advocate a particular point of view. My classes have had debates on everything from the pros and cons of gay marriage and gay adoption to legal issues relating to the harassment of LGBT people at work. When engaging in debates, students must become wellversed in a particular viewpoint, regardless of their personal views. Thus, a pro-LGBT rights student may, because of the luck of the draw, be assigned to debate on behalf of the Catholic Church in the Massachusetts Supreme Court's pro-gay marriage decision, or an anti-LGBT rights student may have to argue on behalf of the lesbian couple who brought the case.

\section{PART TwO: StUdent SAMPLE, QUESTIONNAIRE DESIGN AND METHODOlOGY}

The questionnaire was administered to the 119 students who attended my classes between 1996 and 2005. Every class after 1996 was taught at the same small, private college, in which the overall student body is overwhelmingly white and self-identified as heterosexual and conservative leaning. The 1996 class was taught at a large public university in which the overall student population was more racially diverse and represented a broader range of political viewpoints.

Since the course is an elective and the students who take it self-select, demographics in the class did not necessarily reflect overall campus demographics. Thus, the data collected cannot be considered statistically 
significant. However, the data does the important job of contextualizing other studies, such as the Boston Globe survey ${ }^{50}$, on the nature of attitudes the young hold about gay rights and the role education plays in influencing those attitudes.

The questionnaire was given to students on the last day of class at the end of the term. Depending on the semester, class size ranged from 15 to 30 students. Students were told that completing the questionnaire was voluntary, and that their answers would remain anonymous. A system was adopted in which student answers were kept confidential until after I turned in their final grades. Everyone who attended the class chose to fill out the questionnaire.

The questionnaire consisted of open-ended questions in which the students were given the opportunity to respond with narrative comments. For instance, one question asked students about the extent to which large class discussion vs. small group discussion was more conducive to their feeling comfortable talking and sharing with others about personal issues relating to the topics we were covering. Narrative answers were then coded. For example, if a student wrote that he or she felt most comfortable talking in small groups about when they first learned about homosexuality and what their initial reaction was to what they learned, this answer would be coded "Small Groups 1. Comfortable". A research colleague reviewed my coding of two semesters' worth of answers to check for coding reliability.

The questionnaire covered questions about the following areas:

- Demographics, including age, gender, race, religious affiliation and sexual orientation.

- Attitudes about classroom dynamics, including the extent to which small or large class discussion, or individual writing assignments worked as an effective pedagogical technique.

- The extent to which students heard comments about religion or sexual orientation that made them uncomfortable, and how they reacted to that discomfort (e.g., by being silent, speaking out, etc.)

- The extent to which students experienced a change in belief or attitude about LGBT rights issues, and if so, what changed.

\section{PART THREE: ANALYSIS OF QUESTIONNAIRE DATA}

\section{A. Demographics}

\section{Race and Ethnicity}

The large majority of the 119 students who responded to the survey selfidentified as white $(66.4 \%)$. Blacks made up $15.9 \%$ of the classes, Southeast Asians $-6.2 \%$, and Asians $-3.6 \%$. 5.3\% of the students described themselves as "mixed." Students falling into other racial and ethnic categories were present in much smaller numbers.

50. Supra note 4 . 
Race

\begin{tabular}{|ll|c|c|}
\hline & & Frequency & Valid Percent \\
\hline Valid & White American Born & 74 & 65.5 \\
& White Foreign Born & 1 & .9 \\
& Black American Born & 14 & 12.4 \\
& Black Foreign Born & 4 & 3.5 \\
& Hispanic Foreign Born & 1 & .9 \\
& Asian American Born & 3 & 2.7 \\
& Asian Foreign Born & 1 & .9 \\
& Southeast Asian American Born & 7 & 6.2 \\
& Mixed American Born & 6 & 5.3 \\
& Other & 2 & 1.8 \\
Missing & Total & 113 & 100.0 \\
Total & System & 6 & \\
\hline
\end{tabular}

2. Gender

The classes contained mostly females $(52.9 \%)$, with a sizeable number of males (47.1\%) also present.

\section{Gender}

\begin{tabular}{|ll|c|c|}
\hline & & Frequency & Valid Percent \\
\hline Valid & Male & 48 & 47.1 \\
& Female & 54 & 52.9 \\
& Total & 102 & 100.0 \\
Missing & System & 17 & \\
Total & & 119 & \\
\hline
\end{tabular}

\section{Sexual Orientation}

The vast majority of students identified as heterosexual (94.1\%). During the seven times that this course has been taught, only 4 students identified as lesbian (3.9\%), 1 student identified as bisexual (1\%) and 1 student identified as a gay male $(1 \%)$. 
Sexual Orientation

\begin{tabular}{|ll|c|c|}
\hline & & Frequency & Valid Percent \\
\hline Valid & Heterosexual Male & 51 & 50.0 \\
& Heterosexual Female & 45 & 44.1 \\
& Gay Male & 1 & 1.0 \\
& Lesbian Female & 4 & 3.9 \\
& Bisexual & 1 & 1.0 \\
& Total & 102 & 100.0 \\
Missing & System & 17 & \\
Total & & 119 & \\
\hline
\end{tabular}

\section{Religion}

Most of the students self-identified as Christian (61.1\%). Students also identified as Jewish (10.2\%), Hindu (3.7\%), Muslim (2.8\%), Nondenominational Spiritual (i.e. not affiliated with any particular denomination) $(2.8 \%)$ or Other (1.9\%). A large minority of students said that they were either Nonreligious, Agnostic, or Atheist (17.6\%).

Religion

\begin{tabular}{|ll|c|c|}
\hline & & Frequency & Valid Percent \\
\hline Valid & Christian Catholic & 33 & 30.6 \\
& Christian Protestant & 16 & 14.8 \\
& Christian Other & 17 & 15.7 \\
& Jewish & 11 & 10.2 \\
& Muslim & 3 & 2.8 \\
& Hindu & 4 & 3.7 \\
& Spiritual & 3 & 2.8 \\
& Nondenominational & 7 & 6.5 \\
& Nonreligious & 7 & 6.5 \\
& Agnostic & 5 & 4.6 \\
& Atheist & 2 & 1.9 \\
& Other & 108 & 100.0 \\
Missing & Total & 11 & \\
Total & System & 119 & \\
\hline
\end{tabular}

Of the six students who identified themselves as LGBT, one self-identified as Nonreligious, one as Spiritual Nondenominational, and one as Other. The latter student was particularly vocal about his/her disappointment and dissatisfaction with his/her religion of origin. This student explained that $\mathrm{s} /$ he was a "confirmed Roman Catholic, but fell out of practice 2 years ago, currently disgusted and looking for new religion." Two LGBT students, one Muslim and one Christian, did categorize themselves as religious. One student who identified as LGBT did not answer this question. 
B. Classroom Dynamics

1. Hearing and Reacting to Uncomfortable Comments and Discussions

Students were asked about the extent to which they heard things about religion or sexual orientation that made them uncomfortable during class. Their answers are as follows:

\section{a. Religion}

According to the responses, $22.9 \%$ said that they heard things said about religion that made them uncomfortable. Of these $89.1 \%$ said that when this occurred they remained silent and did not express their reactions or views in class. Only $6.7 \%$ of those who identified things that were said about religion said that they felt comfortable expressing their views in such circumstances.

\section{Heard Religion}

\begin{tabular}{|ll|c|c|}
\hline & & Frequency & Valid Percent \\
\hline Valid & Yes & 27 & 22.9 \\
& No & 91 & 77.1 \\
& Total & 118 & 100.0 \\
Missing & System & 1 & \\
Total & & 119 & \\
\hline
\end{tabular}

\section{React Religion}

\begin{tabular}{|ll|l|l|}
\hline & Frequency & Valid Percent \\
\hline Valid & Expressed views & 8 & 6.7 \\
& Silent & 106 & 89.1 \\
& Talked to others outside class & 4 & 3.4 \\
& 1 & .8 \\
Other & 119 & 100.0 \\
Total & \multicolumn{2}{|}{} \\
\hline
\end{tabular}

One Christian student explained how s/he felt when s/he heard others in the class discuss their views on readings about how the Catholic Church historically persecuted Jewish people and currently takes an anti-gay stance with respect to such issues as gay adoption and gay marriage. S/he said: "Most of the comments... were comments/arguments that I had heard before... most times I felt uncomfortable when people attacked Christianity. I got the feeling that some people in the class were strongly opposed to Christians teaching the Bible, God, etc. That's always an uncomfortable situation [because] I feel like I have very little common ground with people who adamantly oppose Christianity. But I don't necessarily think that is a bad thing."

Another Christian student talked about how hard it was to hear and learn about the negative things that have been done to others in the name of her/his religion: "'Religion is bad' - I felt a burning inside; but I kept silent. 'Christians 
are still like that today' - I felt like it might be true... I felt confused;... I bottled it in."

It is interesting to note that the students who felt most uncomfortable with discussions about religion were the students who could probably best be described as liberal - those who categorized themselves as Spiritual or Other. All students in the Spiritual or Other category said that they were uncomfortable with the discussions. Only $23.1 \%$ of the Christian students, $27.3 \%$ of the Jewish students, $21.1 \%$ of the non-religious students, and none of the Muslim and Hindu students expressed this point of view.

\begin{tabular}{|c|c|c|}
\hline & \multicolumn{2}{|c|}{ Heard religion } \\
\hline & Yes & No \\
\hline \multirow[t]{2}{*}{ Christian } & 15 & 50 \\
\hline & $23.1 \%$ & $76.9 \%$ \\
\hline \multirow[t]{2}{*}{ Jewish } & 3 & 8 \\
\hline & $27.3 \%$ & $72.7 \%$ \\
\hline \multirow[t]{2}{*}{ Eastern Religion } & 0 & 7 \\
\hline & $.0 \%$ & $100.0 \%$ \\
\hline \multirow[t]{2}{*}{ Spiritual \& Other } & 5 & 0 \\
\hline & $100.0 \%$ & $.0 \%$ \\
\hline \multirow[t]{2}{*}{ Non-religious } & 4 & 15 \\
\hline & $21.1 \%$ & $78.9 \%$ \\
\hline
\end{tabular}

I suspect that this is because many religions tell their followers to expect to hear negative things about their faith. Indeed, such experiences are equated with challenging yet necessary temptations that test, and ultimately strengthen the faith of adherents. Liberal students not so closely associated with organized religion, however, seem to have the hardest time hearing others express intolerance towards LGBT people that is founded in religious belief to which they do not ascribe. As one student in this category said: "There seemed to be much lack of knowledge around discrimination done by religious groups which surprised me, but I did not vocalize it."

Finally, none of the Muslim or Hindu students said they were uncomfortable with what they heard. In retrospect, I now see that this could in part be because most of the readings covered examples relating to the historical intolerance on the part of the Catholic Church towards non-Christians during such times as the Spanish Inquisition. In the future I will include more readings about intolerance exhibited by non-Christian religions towards other groups.

\section{b. Sexual Orientation}

$29.9 \%$ of the students identified as feeling uncomfortable about comments made about sexual orientation. When this occurred, most $(89.1 \%)$ of them remained silent. While silent in class, some $(6.8 \%)$ did, however, talk to others outside of class about it. 
Heard Sexual Orientation

\begin{tabular}{|ll|c|c|}
\hline & & Frequency & Valid Percent \\
\hline Valid & Yes & 35 & 29.9 \\
& No & 81 & 69.2 \\
& Other & 1 & .9 \\
& Total & 117 & 100.0 \\
Missing & System & 2 & \\
Total & & 119 & \\
\hline
\end{tabular}

\section{React Sexual Orientation}

\begin{tabular}{|ll|l|l|}
\hline & Frequency & Valid Percent \\
\hline Valid & Expressed views & 4 & 3.4 \\
& Silent & 106 & 89.1 \\
& Talked to person outside class & 4 & 3.4 \\
& Talked to others outside class & 4 & 3.4 \\
& Other & 1 & .8 \\
& Total & 119 & 100.0 \\
\hline
\end{tabular}

One student explained why: "This is still a very taboo/gray area and it offends many people. I felt I needed to hold back some of my opinions in this section so not to offend others."

3. Format for Facilitating Open Discussion - Small versus Large Class Discussion; Writing Assignments

Notwithstanding the difficulty many students had speaking about the above topics, some generalizations can be made about which format best enables them to do so. Small group discussions versus large class discussions seem to be better, and writing assignments, in which they are only writing to me, someone they perceive as a trusted teacher, are the best.

Large Class

\begin{tabular}{|ll|c|c|}
\hline & & Frequency & Valid Percent \\
\hline Valid & Comfortable & 59 & 50.9 \\
& Uncomfortable & 55 & 47.4 \\
& Other & 2 & 1.7 \\
& Total & 116 & 100.0 \\
Missing & System & 3 & \\
Total & 119 & & \\
\hline
\end{tabular}


Small Groups

\begin{tabular}{|ll|c|c|}
\hline & & Frequency & Valid Percent \\
\hline Valid & Comfortable & 80 & 68.4 \\
& Uncomfortable & 31 & 26.5 \\
& Other & 6 & 5.1 \\
& Total & 117 & 100.0 \\
Missing & System & 2 & \\
Total & & 119 & \\
\hline
\end{tabular}

Writing Assignments

\begin{tabular}{|ll|c|c|}
\hline & & Frequency & Valid Percent \\
\hline Valid & Comfortable & 93 & 80.2 \\
& Uncomfortable & 16 & 13.8 \\
& Other & 7 & 6.0 \\
& Total & 116 & 100.0 \\
Missing & System & 3 & \\
Total & & 119 & \\
\hline
\end{tabular}

With respect to small groups, one student said: "I like small group discussions better because I felt there were not as many people possibly judging what you were going to say." Another said: "I am more apt to ask others how they feel in a small group discussion; small group discussions boost my confidence to [speak] honestly." And with respect to writing assignments: "I had no difficulty sharing my opinion in writing assignments. You were extremely successful in establishing trust between yourself and students and an open mentality that was not contingent upon agreement."

\section{Changes in Attitudes}

$53.3 \%$ of the classes said that they had changed their ideas about certain topics since taking the class. $47.1 \%$ said this would affect their future thoughts, and $39.5 \%$ said it would affect their future actions.

Changed Ideas

\begin{tabular}{|ll|r|r|}
\hline & & & \\
& & Frequency & V alid Percent \\
\hline V alid & Yes & 48 & 53.3 \\
& No & 38 & 42.2 \\
& O ther & 4 & 4.4 \\
& Total & 90 & 100.0 \\
M issing & System & 29 & \\
Total & & 119 & \\
\hline
\end{tabular}


Future Ideas

\begin{tabular}{|ll|c|c|}
\hline & Frequency & Valid Percent \\
\hline Valid & Will affect future ideas & 56 & 47.1 \\
& Will affect future actions & 47 & 39.5 \\
& No change & 16 & 13.4 \\
& Total & 119 & 100.0 \\
\hline
\end{tabular}

With respect to general attitudes about difference, one student said: "I have more of a respect for difference - and I enjoy being in situations where different ideas can be discussed." And another student who identified "future manager" as a career goal wrote: "This class will really affect the way I deal with people in the workplace. This is a course everyone should take simply to confront stereotypes."

The Christian student who described a burning inside whenever s/he heard negative things said about Christianity talked about the effect that exposure to new information and critical thinking can have on one's received wisdoms and opinions: "This class has really opened my eyes to many topics and mindsets that I [don't] think could have been gotten from anywhere else. In the future I will have an open mind and not trust everything that has been 'told to me." "

Another Christian student, however, was not so willing to question the teachings of her/his faith, and put what s/he learned in the class in the context of those teachings:

As far as practices, I'll be more willing to listen to what people have to say or how they feel. I will also be aware that I don't have to agree with them to treat them equally - but by equally I don't mean "giv[ing] them everything they want." In the end, everyone's held to God's standards whether or not they want to be.

With respect to LGBT issues, one Christian student had a semi-epiphany about his/her use of what s/he had previously considered harmless, everyday slang: "I realized my friends and me use the term "gay" to talk about something being bad. ... I now stop myself and friends from doing this because I never know who could be around that would take this offensively (even though my intentions are not to disrespect anyone)." I say semi-epiphany because, although this student now realizes that the manner in which s/he uses of the term, "gay," probably offends most LGBT people, s/he is still not ready to admit that the way $\mathrm{s} /$ he uses the the term is still problematic because its effect is to unduly marginalized LGBT people and all things associated with them.

Another Christian student, however, was ready to make this connection and at least start to do the challenging internal work that unlearning homophobia requires. This student said: "I am always hesitant to reveal my thoughts about lesbians and gays when someone comes out and says "I'm homosexual." I've used derogatory terms... and I'm not proud of this. Especially when someone like [X-a classmate] . . tells me that ... [he or she is a 
gay man or a lesbian]. I learned that sexual orientation is something that shouldn't be an issue, but constantly is. I want to work on ways to change that within myself." Still, for all his/her realizations about the power of words to hurt and demean, this same student said: "I still don't know where I stand in regards to gay marriage and gay adoption. The readings gave me some information but I still feel I have to explore and read more before I form a strong opinion."

\section{CONCLUSION}

As anyone who listens to talk radio or has watched recent national political debates knows, we are a deeply divided country when it comes to talking about differences of any kind. Instead of reasoned dialogue in which people try to bridge their differences, too often people demonize one another when they disagree, especially when those disagreements concern LGBT rights. This demonization influences young people, many of whom cling rigidly to prejudices about LGBT people without ever getting the change to engage in the kind of self-examination that is necessary to become compassionate and independent thinking adults.

Teachers can play a key role in helping students do this by modeling nonjudgmental open mindedness towards students' views on LGBT issues. This includes nurturing and welcoming the views and feelings of LGBT students and their classroom allies, as well as demonstrating sensitivity and respect for the role that religious belief plays in certain student attitudes about LGBT rights. It also means pushing every student to examine all viewpoints about LGBT rights in an intellectually rigorous manner.

As the ground rules and exercises discussed above show, teachers can model certain behaviors to ensure that trust is established with their students so that competing student needs and expectations are managed in a manner that maximizes inclusiveness and learning for all concerned. I have found that once this trust is established many of my students have been inspired to replace their more hostile positions with a desire for connection with others they may have previously tried to avoid. Each and ever time this occurs, the grip of intolerance is loosened and LGBT people are able to move a little more freely in the classroom, and hopefully, the world at large. 